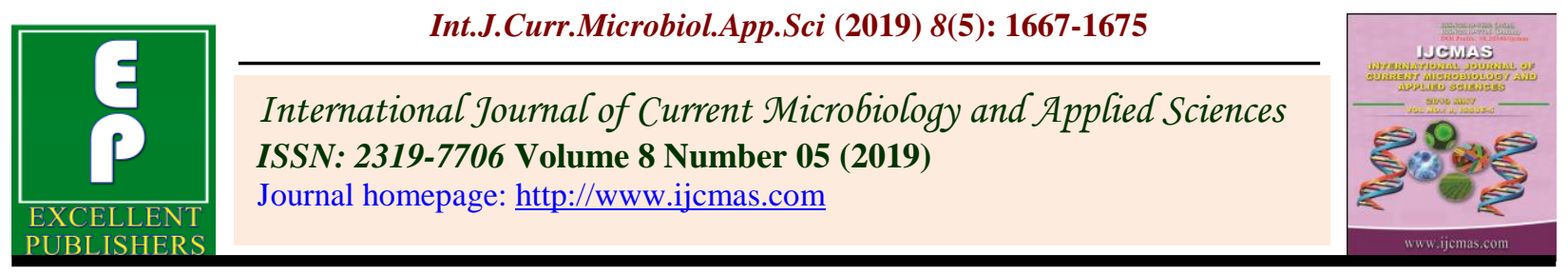

Original Research Article

https://doi.org/10.20546/ijcmas.2019.805.192

\title{
Studies on the Impact of Growing Transgenic Cotton on Soil Health in Major Bt Cotton Growing Areas of Tamil Nadu, India
}

\author{
T. Sherene ${ }^{1 *}$ and Bharathikumar ${ }^{2}$ \\ ${ }^{1}$ Department of soil science \& agricultural chemistry, Anbil Dharmalingam Agricultural \\ College \& Research Institute, TNAU, Trichy, Tamil Nadu, India \\ ${ }^{2}$ Cotton Research Station, TNAU, Veppanthattai, Perambalur, Tamil Nadu, India
}

*Corresponding author

\section{A B S T R A C T}

\section{Keywords}

Soil health,

Transgenic cotton, Soil biological índices

Article Info

Accepted:

15 April 2019

Available Online:

10 May 2019
There is a persistent environmental concern that transgenic Bt-crops have indirect undesirable effect to natural and agroecosystem function. We investigated the effect of Btcotton (with Cry 1 Ac gene) on soil biology in Bt cotton growing soils of Perambalur district, Tamil Nadu under rainfed scenario. Soil samples randomly from ten Bt cotton growing fields were selected in each of the taluks of Perambalur district of TamilNadu region, India, where Bt-cotton has been growing at least for ten continuous years and side by side non-Bt cotton grown soils were also collected to compare the extent of adverse effect of Bt toxin, if any. Samples were analyzed for various soil biological indicators like microbial population, microbial respiration, Microbial Biomass Carbon (MBC), Microbial Biomass Nitrogen (MBN), and soil Dehydrogenase (DHA) activities. The soil biological indicators like microbial population, soil respiration, $\mathrm{DHA}, \mathrm{MBC}$ and $\mathrm{MBN}$ were found to be comparitively higher in Btgrown soils than their non $\mathrm{Bt}$ counter parts over a period of 10 years.

\section{Introduction}

There is a growing concern about cultivating transgenic cotton and its effects on general soil health. Most of the studies on impact of transgenic crops on soil properties carried out were restricted to contained conditions (Liu et al., 2005). Although some research has examined the environmental impacts of the 'aboveground' portion of transgenic crops, relatively fewer research effort has focused on the effects of these crops on soil microbes (Bruinsma et al., 2003) although no risk of growing transgenic Bt cotton on soil health is reported (Sun et al., 2007, Sarkar et al., 2009).Biological indicators of soil quality that are commonly measured include soil organic matter, respiration, microbial biomass (total bacteria and fungi,) and mineralizable nitrogen. The Bt-toxin has the potential to enter the soil system throughout the Btcotton-growing season, through root release and root turn over processes (Motavalli et al., 2004). While Bt occurs naturally in soil, growth of transgenic Bt-crop causes a large increase in the amount of Cry endotoxin 
present in agricultural systems, e.g. roughly $0.25 \mathrm{~g} \mathrm{ha}^{-1}$ produced naturally (calculated from approximately 1000 Bacillus thuringiensis spores $\mathrm{g}^{-1}$ soil (Blackwood and Buyer 2004). Genetically modified cotton genotypes incorporating a crystal (Cry) toxin producing crylAc gene derived from Bacillus thuringiensis $(\mathrm{Bt})$ were introduced in India for commercial cultivation in the year 2002 (Morse et al., 2005). The transgenic crop, now popularly called $\mathrm{Bt}$ cotton, represents about $90 \%$ of cotton cultivated area in TamilNadu, India. In India, no comprehensive field study is available on the effects of growing transgenic cotton on soil biology. We evaluated the effects of growing transgenic $\mathrm{Bt}$ cottons and their counterpart (non-transgenic cotton) on selected soil biological attributes under rainfed conditions of Perambalur district in deep Vertisol.

\section{Materials and Methods}

\section{Soil sampling}

Rhizosphere soil samples were collected 10 days before the harvest of crop at $30-45 \mathrm{~cm}$ depth from transgenic cotton growing fields of various taluks viz., Perambalur, Veppanthattai, Alathur and Veppur of Perambalur district and were labeled and transported back to the laboratory in polyethylene bags and stored at $4^{\circ} \mathrm{C}$ before analysis (Fig. 1). Soil sampling was also done in the non Bt cropped areas to assess the soil quality changes if any.

As both cultivars of cotton were alike, except for the presence of the Bt-gene, it was assumed that any differences in soil ecological functions were attributable to the Bt-gene introduction in the cotton genotypes. Normally, Bt cotton will be raised under rainfed conditions during the rainy season (October-December) with $90 \times 45 \mathrm{~cm}$ spacing every year under rainfed scanario. Normal agronomic practices were followed for raising the crop.

\section{Soil biological indices}

\section{Soil microbial population}

Samples (10 g fresh weight) were serially diluted in $90 \mathrm{~mL}$ Ringers solution up to $10^{-3}$ dilution and an aliquot of $1 \mathrm{~mL}$ of the aliquot was pour plated into selective media (nutrient agar for bacteria), Martin's Rose Bengal Agar for fungi, Ken-Knight and Munaier's Agar for actinomycetes and Buffered yeast agar for yeast. The plates were incubated at optimum temperature $\left(28 \pm 1{ }^{\circ} \mathrm{C}\right.$ for bacteria and yeast; $30 \pm 1{ }^{\circ} \mathrm{C}$ for fungi and actinomycetes) in triplicates. The functional groups of microbes were enumerated by following standard microbiological methods (Wollum 1982). The microbial colonies appearing after the stipulated time period of incubation (3 days for bacteria and yeast; 5 days for fungi; 7 days for actinomycetes) were counted as colony forming units and expressed as $\mathrm{cfu} / \mathrm{g}$.

\section{Soil respiration}

Soil respiration was measured as the $\mathrm{CO}_{2}$ evolved from moist soil, adjusted to $55 \%$ water holding capacity and pre-incubated for seven days at $22-25^{\circ} \mathrm{C}$ with $10 \mathrm{~mL}$ of $1 \mathrm{~mol} / \mathrm{L}$ $\mathrm{NaOH}$. The $\mathrm{CO}_{2}$ production was then measured by back titrating un-reacted alkali in the $\mathrm{NaOH}$ traps with $1 \mathrm{~mol} / \mathrm{L} \mathrm{HCl}$ to determine $\mathrm{CO}_{2}-\mathrm{C}$ (Anderson 1982).

\section{Soil microbial biomass carbon (MBC)}

Soil microbial biomass carbon was determined using the $\mathrm{CHCl}_{3}$ fumigationextraction method (Vance et al., 1987). Samples of moist soil (10 g) were used, and $\mathrm{K}_{2} \mathrm{SO}_{4}$-extractable $\mathrm{C}$ was determined using dichromate digestion.

Microbial biomass carbon was calculated using the equation: Biomass $\mathrm{C}=2.64 \mathrm{EC}$, 
Where: $\mathrm{EC}$ - (organic $\mathrm{C}$ in $\mathrm{K}_{2} \mathrm{SO}_{4}$ from fumigated soil) - (organic $\mathrm{C}$ in $\mathrm{K}_{2} \mathrm{SO}_{4}$ from non-fumigated soil).

\section{Soil Microbial biomass Nitrogen (MBN)}

Soil microbial biomass nitrogen was estimated as MBN =EN/0.54 (Brookes et al., 1985) where EN (Extractable Nitrogen) is the difference between $\mathrm{N}$ extracted from fumigated and non-fumigated samples

\section{Dehydrogenase activity (DHA)}

Dehydrogenase activity (DHA) in soils was determined following the method of Casida et al., (1964) by the colorimetric measurement of reduction of 2, 3, 5-triphenyl tetrazolium chloride (TTC). Each soil sample (10 g) was treated with $0.1 \mathrm{~g} \mathrm{CaCO}_{3}$ and incubated for 24 $\mathrm{h}$ at $37^{\circ} \mathrm{C}$. The triphenylformazan formed was extracted from the reaction mixture with methanol and assayed at $485 \mathrm{~nm}$. FDA was measured following the method of Schnürer and Rosswall (1982) using 3, 6-diacetyl fluorescein as substrate and measuring the fluorescence at $490 \mathrm{~nm}$ (Fig. 2 and Table 2).

\section{Statistical analysis}

Significant $(P<0.01$ and $P<0.05)$ differences between $\mathrm{Bt}$ and non-Bt cotton on soil biological attributes were analyzed in the SAS programme (version 9.1). Tukey's multiple comparison tests were done to determine the differences between $\mathrm{Bt}$ and non-Bt cotton crops.

\section{Results and Discussion}

Impact of Bt cotton on soil microbial population

Bacterial and fungal population was significantly higher in $\mathrm{Bt}$ cotton grown soil compare with non-Bt soil at $0-15 \mathrm{~cm}$ depth. Soil bacterial population ranged from $30-58 \mathrm{x}$
$10^{6} \mathrm{CFU} / \mathrm{g}$, Fungal population ranged from 14.3-16.5 x $10^{3} \mathrm{CFU} / \mathrm{g}$ and actinomycetes ranged from 4.0-5.7 x 10 ${ }^{3} \mathrm{CFU} / \mathrm{g}$ in Bt cotton grown soils. Whereas in non $\mathrm{Bt}$ soils, bacterial, fungal and actinomycetes population were in the range of 25-33 x $10^{6}$ $\mathrm{CFU} / \mathrm{g}, 12.0-14.7 \times 10^{3} \mathrm{CFU} / \mathrm{g}$ and 2.8-3.8 x $10^{3} \mathrm{CFU} / \mathrm{g}$ respectively. The increase in microbial population indicates no adverse effects of growing Bt cotton on soil microbial activity. The differences in the microbial population of $\mathrm{Bt}$ and non-Bt cotton hybrids may be attributed to variations in root exudates quantity, composition and root characteristics bring about by the genetic makeup of the cotton rather than expression of cry gene. Previous studies (Yan et al., 2007) have shown that the qualitative and quantitative differences in root exudation of Bt cotton could strongly influence the structure of microbial communities in the rhizosphere. Higher microbial populations in transgenic cotton grown soil were also reported by several workers (Shen et al., 2006, Kapur et al., 2010). Hu et al., (2009) based on their multiple-year cultivation showed that transgenic Bt cotton was not found to affect the rhizosphere functional bacterial population (Table 1).

\section{Impact of Bt cotton on soil respiration}

The soil respiration was in the range of 224 $308 \mu \mathrm{g}$ of $\mathrm{CO}_{2} / \mathrm{g} / \mathrm{h}$ in $\mathrm{Bt}$ cotton grown soils

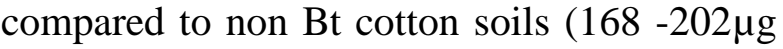
of $\mathrm{CO}_{2} / \mathrm{g} / \mathrm{h}$ ) of various taluks of Perambalur district. Soil respiration rate was significantly $(P<0.01)$ highest in the Bt cotton grown soil followed by non-Bt grown soil.

The increased soil respiration rate with $\mathrm{Bt}$ cotton in our study is the outcome of higher root volume in $\mathrm{Bt}$ cotton compare to non- $\mathrm{Bt}$ cotton that have stimulated the microbial growth and activity by enhanced resource availability (Fig. 3 and Table 2). 
Impact of Bt cotton on soil microbial biomass carbon

Soils under Bt cotton hybrids had an average significantly $(P<0.01)$ higher amounts of $\mathrm{MBC}$ in the range of $175-191 \mu \mathrm{g} / \mathrm{g}$ compared with the non-Bt $162-170 \mu \mathrm{g} / \mathrm{g}$. The increased $\mathrm{MBC}$ in the soil grown with $\mathrm{Bt}$ cotton is attributed to higher root volume compared with non-Bt cotton.

Possibly readily metabolizable carbon and nutrient availability at Bt cotton rhizosphere and differences in root exudates are perhaps the most influential factors contributing to increased microbial colonization and subsequent higher $\mathrm{MBC}$ in soils under $\mathrm{Bt}$ cotton. Earlier, Sarkar et al., (2009) reported a significant correlation between root volume of $\mathrm{Bt}$ cotton and soil MBC that supports the findings of Lynch and Panting (1980) that soil MBC increased with root growth and rooting density of the crop (Fig. 4).

Impact of Bt cotton on soil microbial bio mass nitrogen

The soil Microbial Biomass Nitrogen was in the range 0.43-1.48 per cent in $\mathrm{Bt}$ cotton grown soils whereas it was 0.073-0.092 per cent in non Bt counter parts (Fig. 5 and Table $3)$.

Table.1 Effect of Bt and non Bt cotton on soil microbial population in Perambalur district (Mean values of ten villages in each taluks)

\begin{tabular}{|c|c|c|c|c|c|c|c|}
\hline \multirow[t]{2}{*}{$\begin{array}{l}\text { SI. } \\
\text { No }\end{array}$} & \multirow[t]{2}{*}{ Taluks } & \multicolumn{3}{|c|}{$\begin{array}{l}\text { General microflora in } \\
\text { Bt cotton grown soils (CFU /g) }\end{array}$} & \multicolumn{3}{|c|}{$\begin{array}{l}\text { General microflora in } \\
\text { non Bt cotton grown soils (CFU /g) }\end{array}$} \\
\hline & & $\begin{array}{l}\text { Bacteria } \\
\times 10^{6}\end{array}$ & $\begin{array}{l}\text { Fungi } \\
\times 10^{3}\end{array}$ & $\begin{array}{l}\text { Actinomycetes } \\
\times 10^{3}\end{array}$ & $\begin{array}{l}\text { Bacteria } x \\
10^{6}\end{array}$ & $\begin{array}{l}\text { Fungi } x \\
10^{3}\end{array}$ & $\begin{array}{l}\text { Actinomycetes } \\
\times 10^{3}\end{array}$ \\
\hline 1. & Veppanthattai & 42 & 15.0 & 4.8 & 29 & 14.7 & 3.8 \\
\hline 2. & Perambalur & 58 & 14.3 & 4.0 & 33 & 13.8 & 2.8 \\
\hline 3. & Alathur & 30 & 14.8 & 5.2 & 25 & 12.0 & 2.9 \\
\hline \multirow[t]{3}{*}{4.} & Veppur & 35 & 16.5 & 5.7 & 25 & 14.3 & 3.1 \\
\hline & Rangevalues & $30-58$ & 14.3-16.5 & 4.0-5.7 & $25-33$ & $12.0-14.7$ & 2.8-3.8 \\
\hline & SD & 8.034 & 1.491 & 0.56 & 4.877 & 1.913 & 0.814 \\
\hline
\end{tabular}

Table.2 Effect of Bt and non Bt cotton on soil microbial respiration and Dehydrogenase activity in soils of Perambalur district (Mean values of ten villages in each taluks)

\begin{tabular}{|c|c|c|c|c|c|}
\hline \multirow[t]{2}{*}{ S.No. } & \multirow[t]{2}{*}{ Taluks } & \multicolumn{2}{|c|}{ Bt cotton grown soils } & \multicolumn{2}{|c|}{ Non Bt cotton grown soils } \\
\hline & & $\begin{array}{l}\text { DHA } \\
(\mu \mathrm{g} \text { TPF } / \mathrm{g} / \mathrm{h}\end{array}$ & $\begin{array}{l}\text { Soil respiration } \\
\mu \mathrm{g} \text { of } \mathrm{CO}_{2} / \mathrm{g} / \mathrm{h}\end{array}$ & $\begin{array}{l}\text { DHA } \\
(\mu \mathrm{g} \text { TPF } / \mathrm{g} / \mathrm{h}\end{array}$ & $\begin{array}{l}\text { Soil respiration } \\
\mu \mathrm{g} \text { of } \mathrm{CO}_{2} / \mathrm{g} / \mathrm{h}\end{array}$ \\
\hline 1. & Veppanthattai & 0.2137 & 224 & 0.071 & 164 \\
\hline 2. & Perambalur & 0.2281 & 264 & 0.068 & 181 \\
\hline 3. & Alathur & 0.1983 & 308 & 0.075 & 202 \\
\hline \multirow[t]{3}{*}{4.} & Veppur & 0.1739 & 286 & 0.079 & 201 \\
\hline & Rangevalues & $0.174-0.228$ & 224-308 & 0.068-0.079 & 168-202 \\
\hline & SD & 0.024 & 26.464 & 0.006 & 16.494 \\
\hline
\end{tabular}


Table.3 Effect of Bt and non Bt cotton on soil Microbial Biomass Carbon (MBC) and Microbial Biomass Nitrogen (MBN) in soils of Perambalur district

(Mean values of ten villages in each taluks)

\begin{tabular}{|l|l|l|l|l|l|}
\hline S.No. & Taluks & \multicolumn{2}{|l|}{ Btcottongrownsoils } & \multicolumn{2}{l|}{ Non Btcottongrownsoils } \\
\cline { 3 - 7 } & & MBC $(\boldsymbol{\mu g} / \mathbf{g})$ & MBN $(\%)$ & MBC $(\boldsymbol{\mu g} / \mathbf{g})$ & MBN $(\%)$ \\
\hline 1. & Veppanthattai & 191 & 1.481 & 170 & 0.0813 \\
\hline 2. & Perambalur & 185 & 0.784 & 165 & 0.0732 \\
\hline $\mathbf{3 .}$ & Alathur & 175 & 0.427 & 162 & 0.0835 \\
\hline 4. & Veppur & 181 & 0.691 & 169 & 0.0918 \\
\hline & Rangevalues & $\mathbf{1 7 5 - 1 9 1}$ & $\mathbf{0 . 4 3 - 1 . 4 8}$ & $\mathbf{1 6 2 - 1 7 0}$ & $\mathbf{0 . 0 7 3 - 0 . 0 9 2}$ \\
\cline { 2 - 6 } & SD & $\mathbf{4 . 6 7 1}$ & $\mathbf{0 . 3 1 0}$ & $\mathbf{3 . 2 7 3}$ & $\mathbf{0 . 0 0 7}$ \\
\hline
\end{tabular}

Fig.1 District Map of Perambalur, TamilNadu, India

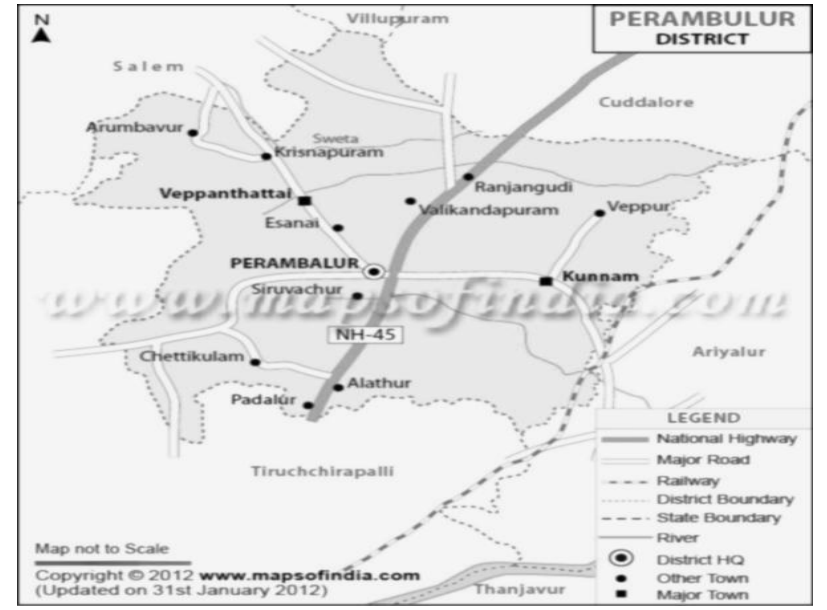

Fig.2

Fig.2 Dehydrogenase activity
0.25
0.2
0.15
0.1
0.05
0

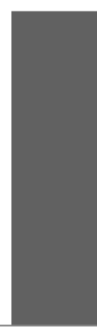
Perambalur
Veppanthattai

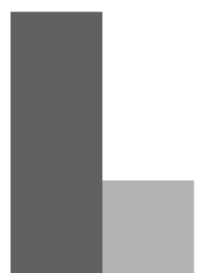
Alathur
Veppur
- Bt cotton grown soil DHA ( $\mu \mathrm{g} \mathrm{TPF} / \mathrm{g} / \mathrm{h}$
Non Bt cotton grown soil DHA $(\mu \mathrm{g} \mathrm{TPF} / \mathrm{g} / \mathrm{h}$ 
Fig.3

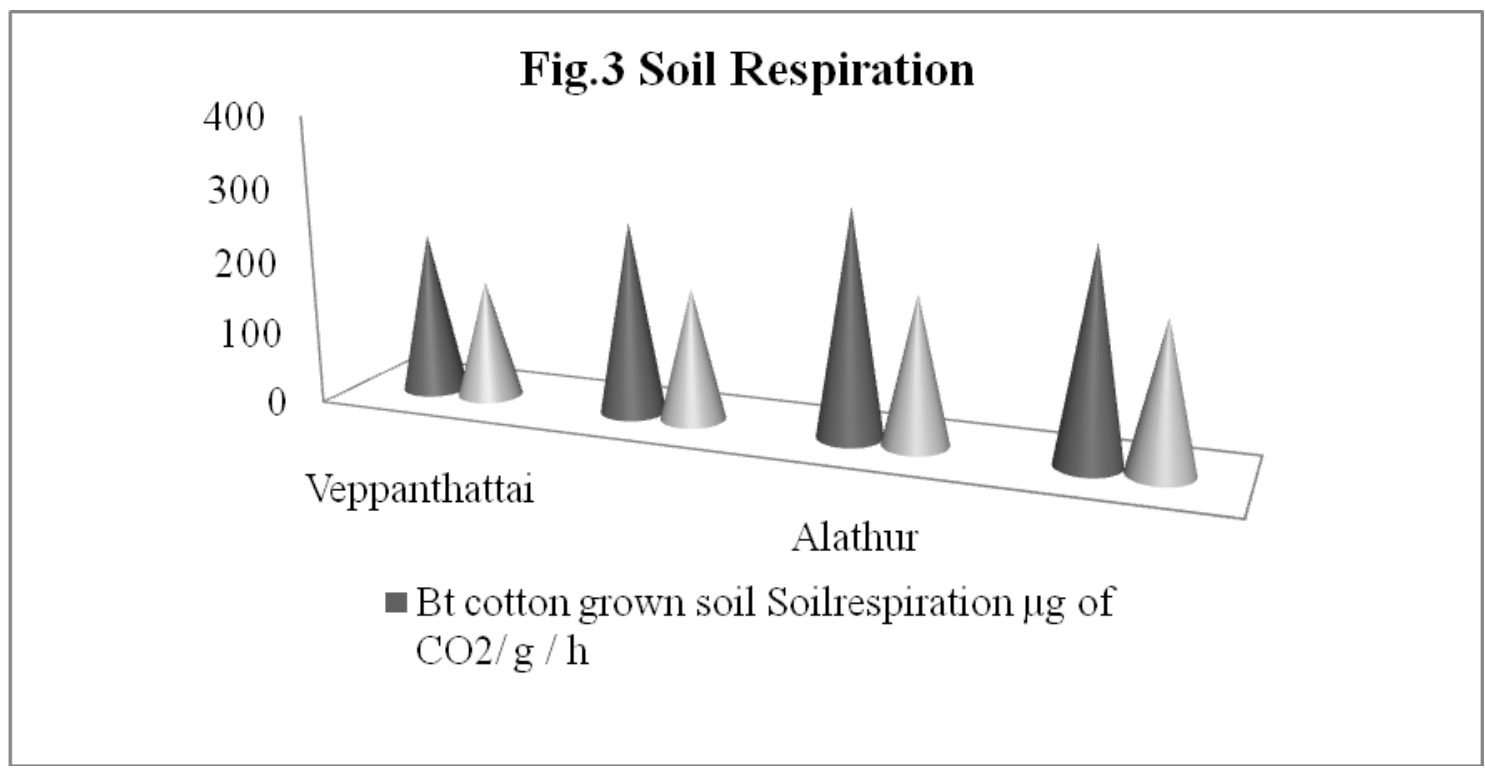

Fig.4

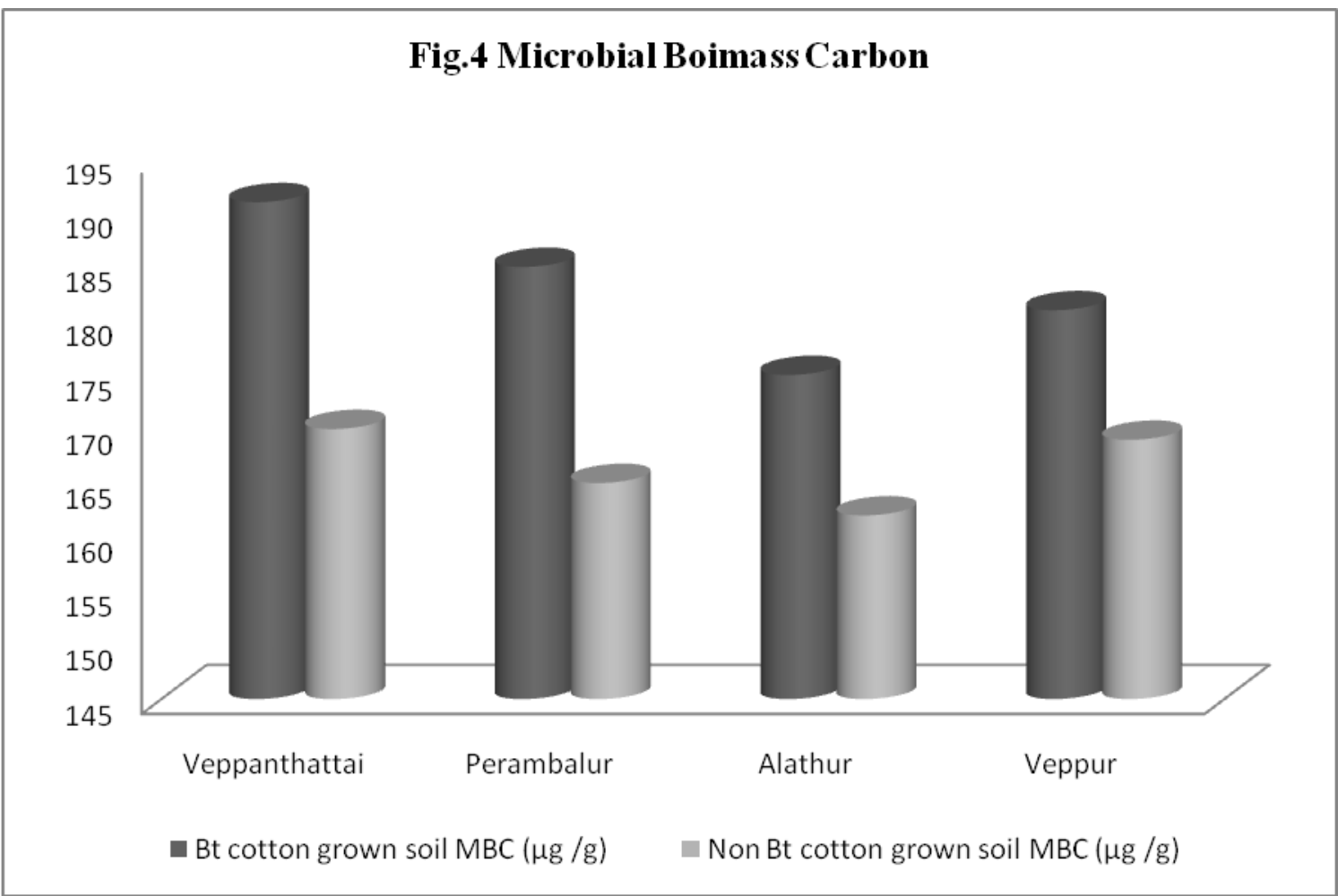


Fig.5

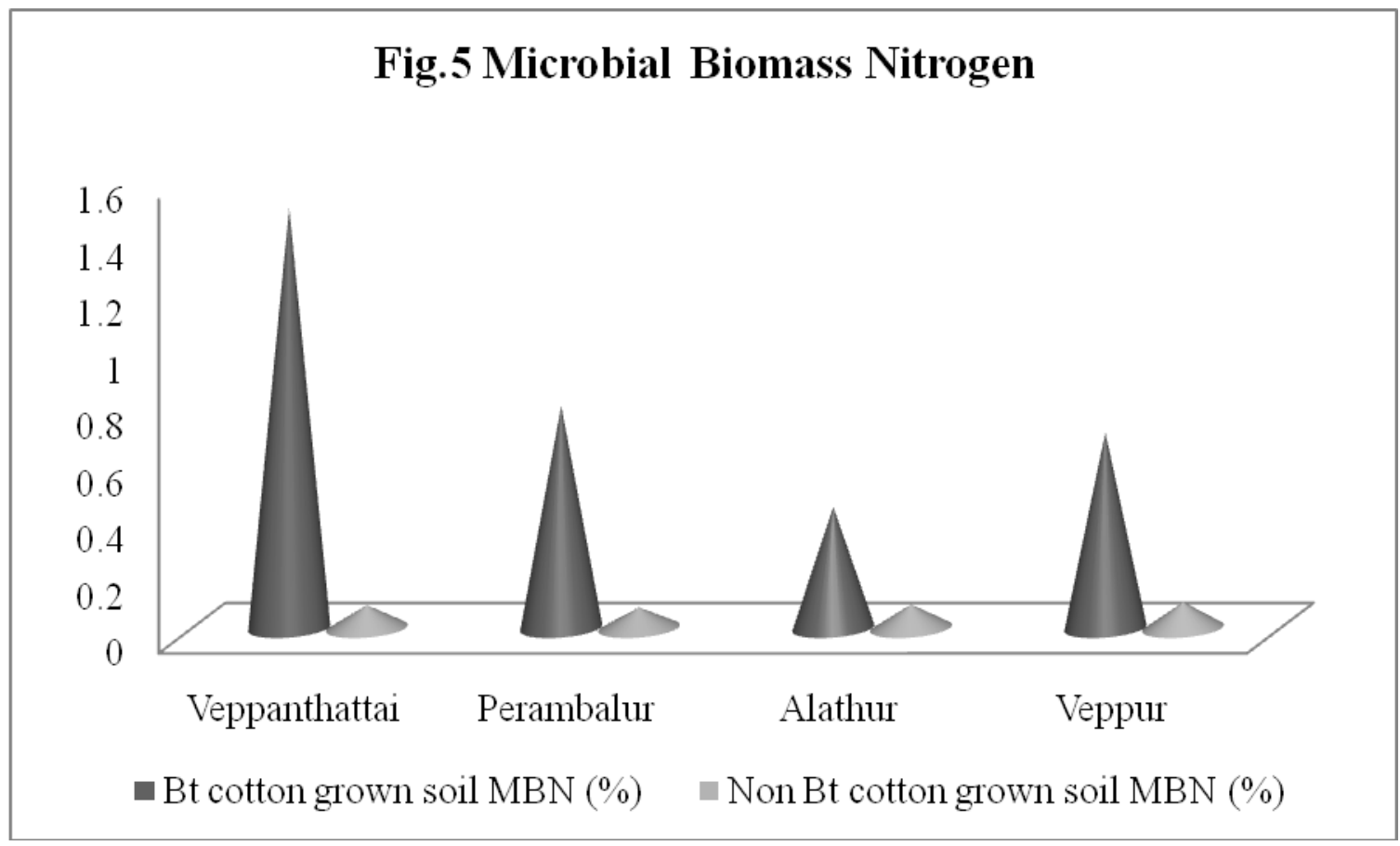

The increased MBN in the soil grown with $\mathrm{Bt}$ cotton is attributed to higher root volume compared with non-Bt cotton. This might be due to comparitively higher root volume and associated biomass of $\mathrm{Bt}$ cotton that serve as a substrate for microbes to act and react with the soil when compared to its non Bt.

\section{Impact of Bt cotton on soil dehydrogenase activities}

Soil enzymes were suggested as one of the potential biological indicators of soil quality because of their relationship to soil biology, ease of measurement, and rapid response to changes in soil management. In our present study, the soils under Bt cotton had higher dehydrogenase activities $(0.174 \quad-0.228 \mu \mathrm{g}$ $\mathrm{TPF} / \mathrm{g} / \mathrm{h})$ than under non-Bt (0.068-0.079 $\mu \mathrm{g}$ $\mathrm{TPF} / \mathrm{g} / \mathrm{h}$ ) crop. DHA is considered as an indicator of the oxidative metabolism in soils and thus of the microbiological activity (Garcia et al., 1997) because it is linked to viable cells. Soil DHA reflects the total range of oxidative activity of soil microflora and, consequently it may be a good indicator of microbiological activity in the soil (Skujins 1976). Positive correlations between dehydrogenase activity and $\mathrm{Bt}$ cotton cultivation are also reported (Singh et al., 2013). DHA in soil depends on the content of soluble organic carbon (Zaman et al., 2002) and the increased organic matter in the surface soil horizon enhanced the soil enzyme activities. Studies by Furczak and Joniec (2007) showed that stimulation of DHA was accompanied by an increase in the number of the microbial groups and improvement in other living conditions (aeration and moisture). The low dehydrogenase activity indicates the low biological activity mainly due to the low soil organic carbon and the calcareous nature of the soil and poor soil fertility status in rainfed condition (James, 2002a, b; Benedict and Ring, 2004).

In conclusion, this study has demonstrated that cultivation of transgenic Bt cotton expressing crylAc gene had no adverse effects on soil biological activities such as microbial population, soil respiration, dehydrogenase activity, microbial biomass carbon, and microbial bio mass nitrogen. Based on the overall 
observations, growing Bt cotton was found to have a positive impact on soil biological activities. Our results suggest that cultivation of Bt cotton expressing crylAc gene may not pose ecological or environmental risk. Thus, the transgenic plants, either through the products of introduced genes and modified rhizosphere chemistry or through altered crop residue quality, have the potential to significantly change the essential ecosystem functions such as nutrient mineralization, carbon turnover and plant growth under long run. It needs continuous monitoring of $\mathrm{Bt}$ cotton grown soil environment for their biological indicators.

\section{References}

Anderson J.P.E. 1982. Soil respiration. In: Page A.L., Miller R.H., Keeney D.R. (eds.): Methods of Soil Analysis. Part 2 Chemical and Microbiological Properties. $2^{\text {nd }}$ Edition. ASA and SSSA, Madison, 837-871.

Benedict, J.H. and D.R. Ring. 2004. Transgenic crops expressing $\mathrm{Bt}$ proteins: current status, challenges and outlook. In: Koul, O., Dhaliwal, G.S. (eds.), Transgenic Crop Protection: Concepts and Strategies. Science Publishers, Inc., Enfield, NH, USA, pp. 15-83.

Blackwood, C.B. and J.S. Buyer. 2004. Soil microbial communities associated with $\mathrm{Bt}$ and non-Bt corn in three soils. Journal of Environmental Quality, 33: 832-836

Brookes, P.C., A. Landham, G. Pruden and D.S. Jenkinson 1985. Chloroform fumigation and the release of soil nitrogen: A rapid direct extraction method to measure microbial biomass nitrogen in soil. Soil Biology and Biochemistry, 17: 837-842.

Bruinsma M., G.A. Kowalchuk, J.A. van Veen 2003. Effects of genetically modified plants on microbial communities and processes in soil. Biology and Fertility of Soils, 37: 329-337.

Brusetti L., P. Francia, C. Bertolini, A. Pagliuca, S. Borin, C. Sorlini, A. Abruzzese, G. Sacchi, C. Viti, L.
Giovannetti, E. Giuntini, M. Bazzicalupo and Daffonchio, D. 2005. Bacterial communities associated with the rhizosphere of transgenic $\mathrm{Bt} 176$ maize (Zea mays) and its non transgenic counterpart. Plant and Soil, 266: 11-21.

Casida L.E., D.A. Klein, T. Santoro 1964. Soil dehydrogenase activity. Soil Science, 98: 371-376.

Furczak J. and J. Joniec. 2007. Changes in biochemical activity of podzolic soil under willow culture in the second year of treatment with municipal-industrial sewage sludge. International Agrophysics, 21: 145-152.

Garcia C., T. Hernandez, F. Costa. 1997. Potential use of dehydrogenase activity as an index of microbial activity in degraded soils. Communications in Soil Science and Plant Analysis, 28: 123-134.

Hu H.Y., X.X. Liu., Z.W. Zhao, J.G. Sun, Q.W. Zhang Q.W, X.Z. Liu, Y. Yu. 2009. Effects of repeated cultivation of transgenic $B t$ cotton on functional bacterial populations in rhizosphere soil. World Journal of Microbiology and Biotechnology, 25: 357-366.

James, C. 2002. Preview: Global status of commercialized transgenic crops: 2002. ISAAA Briefs No. 27, Ithaca, NY. Retrieved from http://www.Isaaa.org/S

Kapur M., R.Bhatia, G. Pandey, J. Pandey, G.Paul D, R.K Jain. 2010. A case study for assessment of microbial community dynamics in genetically modified Btcotton crop fields. Current Microbiology, 61: 118-124.

Liu B., Q. Zeng, F. Yan, H. Xu and C. Xu. 2005. Effects of transgenic plants on soil microorganisms. Plant and Soil, 271: 113.

Lynch J.M., L.M. Panting. 1980. Cultivation and the soil biomass. Soil Biology and Biochemistry, 12: 29-33.

Morse S., R.M. Bennett and Y. Ismael. 2005. Genetically modified insect resistance in cotton: Some farm level economic impacts in India. Crop Protection, 24: 433-440. 
Motavalli, P.P., R.J. Kremer, M. Fang and N.E. Means. 2004. Impact of genetically modified crops and their management on soil microbially-mediated plant nutrient transformations. Journal of Environmental Quality, 33: 816-824.

Sarkar B., A.K.Patra, T. Purakayastha, M.Megharaj.2009. Assessment of biological and biochemical indicators in soil under transgenic $\mathrm{Bt}$ and non- $\mathrm{Bt}$ cotton crop in a sub-tropical environment. Environmental Monitoring and Assessment, 156: 595-604.

Schnürer J., T. Rosswall. 1982. Fluorescein diacetate hydrolysis as a measure of total microbial activity in soil and litter. Applied and Environmental Microbiology, 43: 1256-1261.

Shen R.F., H. Cai, W.H. Gong .2006: Transgenic Bt cotton has no apparent effect on enzymatic activities or functional diversity of microbial communities in rhizosphere soil. Plant and Soil, 285: 149-159.

Singh R.J., I.P. Ahlawat and S. Singh. 2013. Effects of transgenic Bt cotton on soil fertility and biology under field conditions in subtropical inceptisol. Environmental Monitoring and Assessment, 185: 485-495.

Skujins J. 1976. Enzymes in soil. In: McLaren A.D., Peterson G.H. (eds.): Soil
Biochemistry. Marcel Dekker, Inc., New York, 371-414.

Sun C.X., L.J. Chen., Z.J.Wu, L.K.Zhou, Shimizu H. 2007. Soil persistence of Bacillus thuringiensis (Bt) toxin from transgenic Bt cotton tissues and its effect on soil enzyme activities. Biology and Fertility of Soils, 43: 617-620.

Vance E.D., P.C. Brookes and D.S. Jenkinson. 1987. An extraction method for measuring soil microbial biomass $\mathrm{C}$. Soil Biology and Biochemistry, 19: 703-707.

Wollum A.G. 1982. Cultural methods for soil microorganisms. In: Page A.L., Mille R.H., Keeney D.R. (eds.): Methods of Soil Analysis. Part 2 - Chemical and Microbiological Properties. ASA and SSSA, Madison.

Yan W.D., W.M. Shi, B.H. Li, and M. Zhang. 2007. Over expression of a foreign $\mathrm{Bt}$ gene in cotton affects the low-molecularweight components in root exudates. Pedosphere, 17: 324-330.

Zaman M., K.C. Cameron, H.J. Di, and K. Inubushi. 2002. Changes in mineral N, microbial biomass and enzyme activities in different soil depths after surface applications of dairy shed effluent and chemical fertilizer. Nutrient Cycling in Agroecosystems, 63: 275-290.

\section{How to cite this article:}

Sherene, T. and Bharathikumar. 2019. Studies on the Impact of Growing Transgenic Cotton on Soil Health in Major Bt Cotton Growing Areas of Tamil Nadu, India. Int.J.Curr.Microbiol.App.Sci. 8(05): 1667-1675. doi: https://doi.org/10.20546/ijcmas.2019.805.192 